\title{
CHILDBIRTH CARE: THE ORAL HISTORY OF WOMEN WHO GAVE BIRTH FROM THE 1940S TO 1980S ${ }^{1}$
}

\author{
Nathalie Leister², Maria Luiza Gonzalez Riesco ${ }^{3}$
}

\footnotetext{
${ }^{1}$ Extracted from the master's thesis - Transformations in the childbirth care model: oral history of women who gave births from the 1940s to the 1980s, defended at the University of São Paulo (USP), School of Nursing, Graduate Nursing Program in 2011.

2 Doctoral student, USP, School of Nursing, Graduate Program. São Paulo, Brazil. E-mail: natyly@usp.br

${ }^{3}$ Full Professor. Associate Professor, USP, School of Nursing, Maternal-Child and Psychiatric Nursing Department. São Paulo, Brazil. E-mail: riesco@usp.br
}

\begin{abstract}
This study's objective was to gain a greater understanding of the changes that took place in the childbirth care model from the experience of women who gave birth in the State of Sao Paulo, Brazil from the 1940s to the 1980s. This is a descriptive study conducted with 20 women using the Thematic Oral History method. Data were collected through unstructured interviews. The theme extracted from the interviews was "The experience of childbirth". The results indicate a time and generational demarcation in the 1970s. Childbirths from 1940 to 1960 occurred in a context of transition from home to hospital births. The 1980s represents a turning point in the elements that compose the childbirth care model, such as the type and place of birth and the professional assisting women, with an increased use of technology and obstetric interventions.
\end{abstract}

DESCRIPTORS: Parturition. History. Memory. Obstetrics. Obstetrical nursing.

\section{ASSISTÊNCIA AO PARTO: HISTÓRIA ORAL DE MULHERES QUE DERAM À LUZ NAS DÉCADAS DE 1940 A 1980}

RESUMO: O objetivo foi compreender as transformações no modelo de assistência ao parto a partir da experiência de mulheres que deram à luz no Estado de São Paulo nas décadas de 1940 a 1980. Estudo descritivo, pelo método da História Oral Temática, com 20 mulheres. Os dados foram coletados por meio de entrevista não estruturada. O tema extraído das entrevistas foi "A experiência do parto". Os resultados indicaram uma demarcação geracional e temporal nos anos de 1970. Os partos nas décadas de 1940 a 1960 ocorreram no contexto de transição da assistência domiciliar para hospitalar. A década de 1980 representa um momento de inflexão dos elementos que compõem o modelo assistencial, como tipo e local do parto e profissional que assiste a mulher, com incremento da tecnologia e das intervenções obstétricas.

DESCRITORES: Parto. História. Memória. Obstetrícia. Enfermagem obstétrica.

\section{ATENCIÓN AL PARTO: HISTORIA ORAL DE MUJERES QUE DIERON A LUZ EN LAS DÉCADAS DE 1940 A 1980}

RESUMEN: El objetivo fue comprender las transformaciones en el modelo de atención al parto desde la experiencia de mujeres que dieron a luz en el Estado de São Paulo en las décadas de 1940 a 1980. Estudio descriptivo, según la Historia Oral Temática, con 20 mujeres. Los datos fueron recolectados con entrevistas no estructuradas. El tema extraído de las entrevistas fue "La experiencia del parto". Los resultados indicaron una delimitación temporal y generacional en la década de 1970. Los partos en las décadas de 1940 a 1960 ocurrieron en un contexto de transición del domicilio al hospital. La década de 1980 representa un punto de inflexión del modelo de atención, como tipo y lugar del parto y profesional que atiende a la mujer, con incremento de la tecnología y de las intervenciones obstétricas.

DESCRIPTORES: Parto. Historia. Memoria. Obstetricia. Enfermería obstétrica. 


\section{INTRODUCTION}

At the end of the $19^{\text {th }}$ century, most childbirth took place at home and was assisted by midwives. Giving birth outside of the home was considered an uncommon and terrifying event, which happened only in extreme situations. The physician was involved only in complicated cases when a midwife was not able to solve the problem. Socially and economically more accessible than a physician, a midwife offered an additional advantage, that of helping the laboring woman with house chores, replacing or helping her for a while after the delivery. Midwives provided care both at the women's homes and at their own homes. ${ }^{1-2}$

At that time, the hospital environment was not a safe place for women to give birth. Only in 1894, were obstetrical beds installed in theSão Paulo Hospital Maternity in São Paulo, Brazil, where midwives assisted normal deliveries and complicated deliveries were assisted by physicians. ${ }^{2}$

A transition from home birth to hospital birth occurred in the first decades of the $20^{\text {th }}$ century, followed by gradual changes in women's customs. Women started going to obstetrics' and pediatricians' offices for appointments, using medication and buying products from the infant hygiene and feeding industries. Additionally, supply and access to public services for maternal and child health were expanded with a greater participation of philanthropic, quasi-governmental, employers' and workers' institutions. The frequency of hospital births in São Paulo grew from 5\% to 29.5\%, while home births decreased $25 \%$ in 15 years (1930-1945)..$^{3-4}$

The phenomenon of hospital birth is universal and the transition occurred even earlier in Western developed countries. In countries such as the United States, England, France, Norway, and Sweden, the transition from home birth to hospital birth took place in the interwar period, in the early $20^{\text {th }}$ century, while in Brazil hospital birth became a routine procedure only after the 1960s, with the growing expansion of hospital care. ${ }^{4}$

Another factor that accelerated the transition from home birth to hospital birth, and assistance provided by midwives to assistance provided by medical staff, was the creation of the National Institute of Social Security (INPS) in 1967. Through the unification of the pension and retirement institutes, at the expense of the expansion of health companies, the system operated with three components: private; social security for regular employ- ees; and grants from the government (Ministry of Health and State and City Health Departments) to charity institutions to care for the poor.

Hospital births increased by $22 \%$, from $54 \%$ to $76 \%$, between 1968 and the first years INPS was implemented in São Paulo. Therefore, the official model of child delivery care as we know it today was ready and was widely practiced beginning in the 1970s. ${ }^{5}$ In this period, physicians and social security hospitals received more for surgical births than for vaginal births, which gave origin to an epidemic of C-sections. In order to stop the trend toward this type of birth, all deliveries came to be paid the same starting in 1980. The rate of C-sections, however, continued to grow and in $1992,40.5 \%$ of the births in the state, assisted by the Unified Health System (SUS), were C-sections. ${ }^{6}$

In its specific context, the childbirth care model is composed of its own elements, such as environment of care, professionals responsible for providing such care, and a set of practices and procedures. In the general context, the care model is included in the local and national health systems, defined by principles, policies and programs, by the network of services and care coverage, and the participation of users according to their needs and demands.

Also taking into account that the women and families cared for during pregnancy and childbirth are the recipients of care, their experiences in this process should be included as an essential element in the analysis of the care model. It is through the subjectivity and voice of these subjects that the psychosocial and cultural dimensions of childbirth, as a vital event, can be better known.

Researchers have a wide knowledge of the memories of professionals concerning maternity. The memories of mothers, however, have only recently been disseminated in books that tell the experiences of mothers who have given birth in different contexts. Accounts of mothers who gave birth over the course of the $20^{\text {th }}$ century are rare and are not properly highlighted in Brazil, as the records and documents produced by experts and those who devised the first policies for maternalchild healthcare are.

Recovering this memory is relevant not only in order to have records from the perspectives of mothers, but also to compare these memories with those of professionals, given the possibility of understanding what maternity meant to women, how and in what conditions they became mothers, and how the experts influenced their experiences 
and decisions. It is possible, through the memories of mothers, that is, from other perspectives, to understand the context of maternity in the $20^{\text {th }}$ century, which, without such records, tend to be unspecific and limited.

\section{OBJETICVE}

To understand the transformations that took place in the childbirth care model based on the experiences of women who gave birth in the state of São Paulo, Brazil from 1940 to 1980.

\section{METHOD}

This is a descriptive study with a qualitative approach that follows the Thematic Oral History method..$^{7-8}$

Women who gave birth in the state of São Paulo between 1940 and 1989 were considered the study's subjects. The sample was composed of 20 individuals, who were the mothers, grandmothers or great grandmothers of the midwives who graduated in the first class of the Undergraduate Program in Obstetrics of the University of São Paulo, School of Arts, Sciences, and Humanities. The participants were initially contacted, in person or by phone, by the graduate in order to verify the eligibility of his/her mother, grandmother, or great grandmother to participate in the study, to determine if they had given birth in the place and period previously established. The place and date of the interview was then scheduled according to the participant's convenience. The criterion to define the number of women interviewed was the acknowledgement that new information confirmed previous information, and became repetitive and was sufficient to obtain a coherent analysis. ${ }^{9-10}$

Data were collected between August 2010 and January 2011 through recorded interviews based on a script that guided and directed the theme related to the experience of giving birth. We did not establish just a single rigid script to be followed in each of the interviews, because new information and knowledge was added in each interview.

The interview was divided into three stages: pre-interview (meeting held through personal or telephone contact with the midwife in which the interviewee (mother, grandmother or great grandmother) was introduced to the project and given clarification about her participation, also verifying their eligibility and condition to report facts from the past); interview (held on a date and time that was convenient for the interviewee, and was recorded and lasted from $10 \mathrm{~min}$ to $1 \mathrm{~h} 53 \mathrm{~min}$ ); post interview (composed of acknowledgement to the interviewee for her participation in the study, transcription, textualization and transcreation of narratives). ${ }^{8-9}$

Content analysis was performed for the narratives, ${ }^{11}$ which in the thematic modality include: pre-analysis (skimming, construction of the corpus, and transcreation); ${ }^{10}$ exploration of the material (categorization of data through exhaustive reading of the trancreated interviews); and treatment of the results and; interpretation (inferential process, based on the theme that emerged from the narratives and its historicity, context and meanings).

The study was approved by the Institutional Review Board of the University of São Paulo, School of Nursing (Process n.. 941/2010/ CEP-EEUSP) and the participants signed free and informed consent forms and letters of the free transfer of rights concerning their oral testimonies. The participants authorized the use of their first names.

\section{RESULTS AND DISCUSSION}

This study's results refer to data collected from interviews held with 20 women who gave birth from 1940 to 1989. The women who gave birth from 1940 to 1968 were considered to be the $1^{\text {st }}$ generation and those who gave birth between 1981 and 1989 compose the $2^{\text {nd }}$ generation. None of the studied women gave birth in São Paulo between 1969 and 1980. The characterizations of the interviewees are presented descriptively below in chronological order, considering the first labor of each.

\section{Women from the $1^{\text {st }}$ generation}

- Antonieta, 94 years old, normal home birth, in the countryside, with a midwife without episiotomy; accompanied by the mother; attended prenatal care.

- Joana, 79 years old, eight normal home births, in the countryside, with a midwife, without episiotomy; does not recall whether she had a companion; did not attend prenatal care.

- Anézia, 76 years old, three normal home births, metropolitan region, with a midwife, without episiotomy; accompanied by the mother and aunt; attended prenatal care for the last child. 
- Hermínia, 73 years old, four normal childbirths, three at the hospital and one at home, two in the countryside and two in the metropolitan region, all with a midwife; episiotomy in the first birth; accompanied by the husband at home; attended prenatal care for the two last children.

- Cleusa, 83 years old, two normal births and one with forceps at the hospital, in the capital, two with a physician and one with a midwife; all with episiotomy; accompanied by the husband in the first two deliveries; attended prenatal care for all three children.

- M. de Jesus, 70 years old, two home births, in the countryside, with a midwife; episiotomy in the first birth; accompanied by the husband; attended prenatal care for all the children.

- Ignêz, 68 years old, two C-sections and one normal hospital birth, in the capital, with physician and episiotomy; without a companion; attended prenatal care for all three children.

- M. de Lourdes, 68 years old, one normal birth at home, in the capital, with midwife, without episiotomy; accompanied by the father; attended prenatal care.

\section{Women from the $2^{\text {nd }}$ generation}

- Cristina, 59 years old, two normal hospital births, in the countryside, with a physician, without episiotomy; accompanied by the husband; attended prenatal care for both children.

- M. das Graças, 47 years old, one hospital birth with forceps, with episiotomy, and one Csection, in the capital, without a companion, attended prenatal care for both children.

- Vera Lúcia S., 53 years old, two C-sections, in the metropolitan region; without a companion; attended prenatal care for both children.

- Vilma, 53 years old, three normal hospital births, in the capital, two with a physician and one with a nurse, episiotomy in the first two births, and one C-section with a stillborn child; without a companion; attended prenatal care for all four children.

- Sebastiana, 58 years old, two C-sections, in the capital; without a companion; attended prenatal care for both children.

- Sheila, 43 years old, two C-sections, in the capital; without a companion; attended prenatal care for both children.

- Carmen, 49 years old, two normal hospital births, in the capital, with a physician, with episiotomy; without a companion; attended prenatal care for both children.

- Vera Lúcia M., 57 years old, one C-section, in the metropolitan region; without a companion; attended prenatal care.

- Conceição, 51 years old, two C-sections, in the countryside; without a companion; attended prenatal care for both children.

- Valdinéia, 52 years, two C-sections, in the countryside; without a companion; attended prenatal care for both children.

- Noeme, 59 years old, one C-section, in the capital; without a companion; attended prenatal care.

- Marisol, 48 years old, two C-sections, in the capital; without a companion; attended prenatal care for both children.

\section{The experience of birth}

The main elements that stand out as components of the childbirth care model are the environment where the birth occurs, the professional assisting it, and the care practices provided to women during the pregnancy period. These guided the development of the interview script, the interviews and the composition of the theme, based on which the discussion concerning the transformations in the care model is presented.

The maternal and child healthcare policy in Brazil began to be formulated in the 1930s and put into practice beginning in the 1940s, first meeting the demands of larger urban centers and only later, in the 1950s, did smaller cities begin to have childcare health units and maternity hospitals. ${ }^{4}$ Among this study's participants, the majority of those from the $1^{\text {st }}$ generation lived in rural areas or in the urban areas of cities in the interior of São Paulo, where changes in the childbirth care model took place at a later time than in the capital.

Progressively, the hospital became a necessary good and a symbol of social ascension, a place where there would be access to modernity and to a safe and differentiated care, where women could enjoy civility and comfort. Beginning in the 1940s, women were starting to have their children in maternity hospitals and to have the opportunity to give birth in a hospital was perceived as gain in their lives. ${ }^{12}$

This coincides with the reports by the women from the $1^{\text {st }}$ generation, because even though they had given birth at home, they valued the safety 
and technology the hospital birth provided to their daughters and daughters-in-law as something good, a consequence of the modernization and technology that gradually became available for childbirth. The transition from home birth to hospital birth among the interviewed women was mainly accomplished from the 1960s on. In this decade, two women opted to have their babies at the hospital, but no childbirth took place at home in the following years.

The type of professional assisting births is somewhat inseparable from the care environment. Even though, midwives, whether they had a degree or not, were also included on the hospital staff to assist in childbirth, physicians and nurses gradually replaced them in hospital birth. ${ }^{13}$ There were 49 births in the studied period, 16 of which were assisted by midwives and, up to the 1960s, they took place at home. A total of 28 hospital births, out of 33, were assisted by physicians, especially among women from the $2^{\text {nd }}$ generation.

The participants' testimonies show that the reasons midwives were chosen included: being "good", having a degree, being known, being referred by family and friends, living near by, and charging accessible prices. In relation to the physician, the reasons also included: being known or referred by someone, though some women were assisted by a physician appointed by the health insurance company or on duty at the time of labor. There is a clear polarization between the midwives, as the agents assisting births at home for the $1^{\text {st }}$ generation, and the physicians, who assisted the deliveries of women from the $2^{\text {nd }}$ generation at the hospital. Apparently, the supply of professionals and maternity services was expanded for the women from the $2^{\text {nd }}$ generation due to access to slots made available by an agreement with medical companies and the National Institute of Medical Care from Social Security (INAMPS). ${ }^{4,14-15}$

Some of the testimonies express difficulties accessing professional care and the variety of reasons that involved their "choice": [...] my husband sought a good midwife with a degree to assist my labor. In the second pregnancy I swapped midwives because the previous one was costly and this one was poorer and charged less. The birth ( $5^{\text {th }}$ child) was with Maria Luzia, who had a degree. We met her because she lived nearby [...] (Joana); [...] I attended my first consultations with a physician referred by the insurance company, but I hadn't met him before. After seven months of my pregnancy he told me he couldn't assist my labor but didn't tell why, so I went to my gynecologist, Dr.
Mendes, who received me very well and I know he was a good doctor [...] (Noeme).

The eight women from the $1^{\text {st }}$ generation had 25 childbirths, of which two were C-sections and one with forceps. These women recall the pain of childbirth and the fear of going to the hospital, which meant something wrong was happening. Most of these women had a companion, such as their mothers, husband or aunt, who usually provided physical and emotional support. They assessed the midwives' work according to the birth's result, that is, whether they had had a perfect child and an uncomplicated labor. They provided few details about what the midwife would do during labor, but report that care included laboratory exams and physical assessments, prayers, use of oxytocics, cutting and suturing the perineum without anesthesia and maneuvers to help expel the baby and placenta, such as "pushing the belly" and "blow in a bottle".

In regard to the women from the $2^{\text {nd }}$ generation, the 12 women interviewed had 24 deliveries, 16 of which were C-sections. Some C-sections were elective due to complications during the pregnancy (e.g. preeclampsia, placenta previa, and intrauterine fetal death) while others were due to previous C-section, a negative experience in previous normal delivery and fear of the pain experienced in a normal labor.

The women from the $2^{\text {nd }}$ generation experienced fear and loneliness during their hospitalization due to a lack of professional care and/or lack of a companion; most of them were not allowed to have the presence of a companion. They did, however, highlight the importance of having a companion, when they were allowed to have one: [...] my husband wanted to watch all my deliveries, which was very good. I guess it is an emotion that we have to share [...] (Cristina); [...] I guess that every father should watch because it strengthens the bond with the child and with the wife. It should be mandatory, because it was very important to me $[. .$.$] (Sheila); [...]$ nobody would come and see whether everything was normal, nobody came to see my dilation [...] once in a while somebody would come and see me, but I had a feeling of being abandoned because nobody told me the position I should stay in and I had no pillows, nothing [...] (Noeme).

Other negative feelings reported during the labor experience referred to the professionals' harshness, lack of privacy, exposure of intimacy, rigidity of the hospital routines, and invasive procedures such as enema, shaving, amniotomy, 
serum with oxytocics, manual cervical dilation, episiotomy and a lack of clarification or information concerning what was happening to them.

In relation to episiotomies, five women from the $1^{\text {st }}$ generation, among the 22 who had normal deliveries, had an episiotomy, while six out of seven in the $2^{\text {nd }}$ generation received a perineal cut. Episiotomy has been considered an example of practices adopted without evidence of benefits for labor. The National Demographic and Health Survey from 2006 shows that $80.3 \%$ of the women who had normal deliveries in the Southeast had an episiotomy. ${ }^{16}$

Since 1985, recommendations by the World Health Organization, concerning appropriate labor and birth technology, restrict various practices, which women, especially those from the $2^{\text {nd }}$ generation, mention. Among these practices we highlight: indication for C-section due to a previous C-section or to perform tubal ligation; the systematic use of episiotomy and amniotomy; lack of mobility during labor; shaving of pubic hair and being given an enema. ${ }^{17}$ Hence, the care provided to these women was already contrary to what had been internationally recommended.

In regard to care provided to newborns right after birth, women valued skin-to-skin contact with the infants, they were then relieved to know that the child was well and also for the excitement of being in direct contact with the child, strengthening the mother-child bond. The infant calms down when receiving maternal warmth and recognizes the mother. Therefore, this contact is a positive experience and is regarded as a humanized practice in birth care. ${ }^{18}$ Unfortunately, some women from the $2^{\text {nd }}$ generation were not allowed to have this contact due to the interventionist practices adopted in the immediate care provided to newborns.

Most women in the $1^{\text {st }}$ generation had normal deliveries and confirm experiencing a rapid recovery after delivery. They also criticize the care received when reporting complications (e.g. infection in the stiches of the perineum in the hospital birth and hemorrhaging and retained placenta): [...] one month after my first child was born, I went back to the hospital because I had a little infection. The physician said that I needed cleansing and prescribed penicillin. I'm sure it was the doctor's fault, something he did, because I didn't do anything different, uncommon, I did everything as prescribed, including my diet
[...]; [...] she [midwife] took the child, but didn't cut the cord and the placenta got stuck in me, but finally my pain went away [...] they even gave me my father's urine to drink to see if the placenta would come out, it was such ignorance [...] nowadays, even policemen are capable of doing it better than that curious woman [...] (M. de Lourdes).

Five out of the 12 women from the $2^{\text {nd }}$ generation talked about postpartum depression, fear of experiencing depression, and pain after a $\mathrm{C}$-section and pain in the perineal region after normal delivery. In relation to recovery, they reported care required to heal the $\mathrm{C}$-section incision, complications due to surgical infection, and concern with the aesthetics of the abdominal region. These women also report negative experiences in the postpartum period even when there were no complications.

From the 1970s on, female researchers started to reveal the distance and tension existing between the myth of motherhood and the reality experienced by women, who started expressing conflicts and exposing ambivalent feelings, which did not fit the stereotype of a good mother. ${ }^{19}$ These feelings, not verbalized by the women from the $1^{\text {st }}$ generation, appear in the narratives of the women from the $2^{\text {nd }}$ generation: [...] I felt rejection, I wasn't happy. I got depressed during the time I was realizing that I had become a mother [...] it was nuisance when the baby came because I had so much pain. I didn't even want to hold him because I could not move. I was feeling hurt and sore [...] (Vera Lúcia S.); [...] I had nausea and depression after the birth and I didn't believe it existed. I felt like running away, throwing the baby on the bed, leaving and never coming back [...] (Conceição).

A remarkable difference between generations is the contact mothers had with their babies after the delivery depending on the place of birth. If, during home births, mother and child remained together all the time, at the hospital, being separate from the baby was the rule. Even in facilities working with the rooming-in system, the baby would stay in the nursery for some periods of time. Only in the last two decades, especially with the implementation of the Baby Friendly Hospital Initiative*, have maternities hospitals changed the rules and followed a model that condemns the practice of separating mother and child. ${ }^{20}$

In relation to the postpartum period, the testimonies of the women from the $1^{\text {st }}$ generation reveal they did not value self-care in this period (e.g. they report going to a puerperal consultation only

* http://portal.saude.gov.br/portal/saude/visualizar_texto.cfm?idtxt=24229 
if they experienced some problem). In turn, seven interviewees from the $2^{\text {nd }}$ generation reported they attended medical consultations and received guidance during the postpartum period. The difficulty in accessing postpartum care and the devaluation of such care by these women may reflect a policy concerning postpartum care that is not incisive. The results from the evaluations performed by the Program for the Humanization of Prenatal and Childbirth, Brazilian Ministry of Health reveal that less than half of the women who attended the six recommended prenatal consultations in 2002 also attended the postpartum consultation. ${ }^{21}$

The narratives that refer to the women's experiences during pregnancy indicate that even though five of the women from the $1^{\text {st }}$ generation reported having prenatal care for all their children, such care was not habitual for them. There was one testimony expressing mistrust in relation to preparation for the delivery; the passivity of women in prenatal care is also observed. The women from the $2^{\text {nd }}$ generation confirmed the concern of the women from the $1^{\text {st }}$ generation concerning weight control, both due to aesthetic reasons and to their doctors' recommendations to control their diets. Eight out of the 12 interviewees talked about this subject, often recalling the weight they gained.

In regard to care provided by the professionals in prenatal consultations, the main procedures referred to were blood pressure control, listening to the baby's heartbeat with Pinard and sonogram (not available for the $1^{\text {st }}$ generation), blood exam, urine and feces, weighing, measuring fundal height and amniocentesis to assess fetal maturity. The use of vitamins is repeatedly recalled as medication used during pregnancy. Ten out of the 12 women from the $2^{\text {nd }}$ generation report their use.

Many of these procedures and exams were not reported by the women in the $1^{\text {st }}$ generation because only gradually did pregnancy and childbirth come to be seen as a medical and risky event that required systematic monitoring. The improvement in accessing prenatal consultations has repercussions on care, with excessive medication, including ultrasound scanning, episiotomies and C-sections. ${ }^{22}$

None of the women in the $1^{\text {st }}$ generation had an ultrasound test because the equipment was not available in Brazil until the end of the 1960s. In turn, the women from the $2^{\text {nd }}$ generation recall the ultrasound as an important exam for diagnosing the pregnancy, assessing the baby, and determin- ing the child's sex and gestational age. Nine out of the 12 participants had the exam.

According to a study performed with two physicians from Rio de Janeiro and one from Recife, Brazil, considered to be the pioneers of obstetric ultrasounds in Brazil, the exam represents a watershed event in prenatal care. For the pregnant women, it represented the possibility of having "a picture of the baby", which transformed the ultrasound into a consumer good and the exam became a moment of leisure. It also helps to configure the pregnancy as something concrete and not imaginative in creating the image of the baby, anticipating the social existence of the unborn child. The women who had the ultrasound exam perceived it as something beneficial that they liked and valued, without questioning. ${ }^{23-24}$

The women from the $2^{\text {nd }}$ generation experienced other processes during prenatal care, such as the indication of having a C-section as a convenience for the physician or due to a previous C-section; access to health insurance companies; and a lack of commitment on the part of prenatal care service to follow-up the pregnancy after the eighth month.

In the case of elective C-sections, the surgery represented an excellent option for resolving pregnancy, which thanks to the mastery of techniques and improved knowledge in the fields of surgery, antisepsis, and anesthesia, improved the safety of the intervention. ${ }^{25}$ This practice financially benefited physicians and hospitals and was an alternative for those who feared labor.

For women of both generations, the place where they would attend prenatal care and hospital birth depended on public or private facilities, which provided private care, or through a health insurance plan. From the 1970s on, government subsidies were increasingly provided to private companies in order to supply medical care to workers, with the proliferation of private health insurance companies, and expansion in the supply of medical care. ${ }^{15,22}$

The women from the $2^{\text {nd }}$ generation had their children during a time the SUS was being reformulated; changes, however were only implemented in later decades. The current challenges for the SUS concerning maternal and child healthcare are the need to reverse a trend toward excessive medication during labor; to improve quality of care, since access to prenatal care and labor care is already almost universal; and to integrate prenatal care and delivery. ${ }^{15}$ 


\section{CONCLUSION}

Transformations are continuous; there is no specific moment when a rupture between past and current practices occurred. In the beginning of the $20^{\text {th }}$ century, childbirth was almost exclusively normal and at home. Between 1930 and 1960, both home and hospital births coexisted, assisted by midwives and physicians. From the 1970s on, as reported in the interviews from the 1980s, childbirth became exclusively hospital birth assisted by physicians, and most frequently via a C-section.

The reports of the experience of women during labor and the context in which maternity took place indicate there is a generational and temporal demarcation in the 1970s. Thus, before the 1970s, the experience of the women from the $1^{\text {st }}$ generation took place in a context of a care model in transition, while the women from the $2^{\text {nd }}$ generation experienced, from the 1980s on, the consolidation of a hospital-centered birth model.

Maternal memories are narratives of the diversity of practices and feelings regarding childbirth, of how the women appropriated social conventions concerning motherhood, and sought solutions for daily problems and the multiplicity of feelings related to the experience of giving birth and raising children.

\section{REFERENCES}

1. Osava RH. Assistência ao parto no Brasil: o lugar dos não-médicos [tese]. São Paulo (SP): Universidade de São Paulo, Faculdade de Saúde Pública; 1997.

2. Mott ML. Assistência ao parto: do domicílio ao hospital. Projeto História. 2002 Dez; 25:197-219.

3. Instituto Brasileiro de Geografia e Estatística (IBGE). Anuário Estatístico do Brasil: 1949-1971 [online]. Rio de Janeiro (RJ): IBGE. 1971 [acesso 2011 Maio 29]. Disponível em: http://seculoxx.ibge.gov.br/ seculoxx/arquivos_pdf/saude.shtm

4. Martins APV. Memórias maternas: experiências da maternidade na transição do parto doméstico para o parto hospitalar. História Oral. $2005 \mathrm{Jul}-\mathrm{Dez}$; 8(2):61-76.

5. Mott ML. Atendimento ao parto em São Paulo: o serviço obstétrico domiciliar. In: Costa CL, Schmidt $\mathrm{SP}$, organizadores. Poéticas e políticas feministas. Florianópolis (SC): Mulheres; 2004. p.113-23.

6. Ministério da Saúde (BR). AIH pagas segundo município. Partos cesáreos: São Paulo, 1992 [online]. Brasília (DF): Ministério da Saúde. [s.d.] [acesso 2011 Maio 29]. Disponível em: http:/ / tabnet.datasus.gov. br/cgi/tabcgi.exe?sih/cnv/pisp.def
7. Cassab LA. História oral: miúdas considerações para a pesquisa em serviço social. Serv Soc Rev [online]. 2003 [acesso 2010 Jan 21]; 5(2). Disponível em: http://www.uel.br/revistas/ssrevista/c_ v5n2_latif.htm

8. Meihy JCSB. Manual de história oral. $5^{a}$ ed. São Paulo (SP): Loyola; 2005.

9. Ruquoy D. Situação de entrevista e estratégia do entrevistador. In: Albarello L, Digneffe F, Hiernaux JP, Maroy C, Ruquoy D, Saint-Georges P. Práticas e métodos de investigação em ciências sociais. Lisboa: Gradiva; 1997.

10. Meihy JCSB, Holanda F. História oral: como fazer, como pensar. São Paulo (SP): Contexto; 2007.

11. Minayo MCS. O desafio do conhecimento: pesquisa qualitativa em saúde. $11^{\text {a }}$ ed. São Paulo (SP): Hucitec; 2008.

12. Mott MLB. A expedição e o nascimento. In: Museu da cidade de São Paulo. Expedição São Paulo 450 anos: uma viagem por dentro da metrópole. São Paulo (SP): Instituto Florestan Fernandes; 2004. p.197-202.

13. Santos TCF, Barreira IA, Almeida Filho AJ, Oliveira AB. Las dictaduras de Vargas y Franco: implicaciones de la consagración de la maternidad para la enfermería. Texto Contexto Enferm. 2010 Abr-Jun;19(2): 317-24.

14. Fleig J. 'Mães desdobráveis': experiências e memórias da maternidade na segunda metade do século XX [monografia]. Curitiba (PR): Universidade Federal do Paraná; 2009.

15. Paim J, Travassos C, Almeida C, Bahia L, Macinko J. The Brazilian health system: history, advances, and challenges. Lancet. 2011 Mai; 377(9780):1778-97.

16. Lago TDG, Lima LP. Assistência à gestação, ao parto e ao puerpério: diferenciais regionais e desigualdades socioeconômicas. In: Ministério da Saúde (BR). Pesquisa Nacional de Demografia e Saúde da Criança e da Mulher - PNDS 2006: dimensões do processo reprodutivo e da saúde da criança. Brasília (DF): Ministério da Saúde; 2009. p.151-70.

17. World Heath Organisation (WHO). Appropriate technology for birth. Lancet. 1985 Set; 326(8452):4367.

18. Wei CY. Ações humanizadoras na assistência ao parto: experiência e percepção de um grupo de mulheres em um hospital-escola [dissertação]. São Paulo (SP): Escola de Enfermagem, Universidade de São Paulo; 2007.

19. Martins APV. A ciência dos partos: visões do corpo feminino na constituição da obstetrícia científica no século XIX. Estud Fem. 2005 Set-Dez; 13(3):645-66.

20. Lamounier JA, Bouzada MCF, Janneu AMS, Maranhão, AGK, Araújo MFM, Vieira GO et al. Iniciativa Hospital Amigo da Criança, mais de uma 
década no Brasil: repensando o futuro. Rev Paul Pediatr. 2008 Jun; 26(2):161-9.

21. Serruya JS, Cecatti JG, Lago TG. O Programa de Humanização do Pré-natal e Nascimento do Ministério da Saúde no Brasil: resultados iniciais. Cad Saude Publica. 2004 Set-Out; 20(5):1281-9.

22. Victora CG, Aquino EML, Leal MC, Monteiro CA, Barros FC, Swarcwald CL. Maternal and child health in Brazil: progress and challenges. Lancet. 2011 Mai; 377(9780):1863-76.

23. Chazan LK. 'É... tá grávida mesmo! E ele é lindo!' A construção de 'verdades' na ultra-sonografia obstétrica. Hist ciênc saúde-Manguinhos. 2008 JanMar; 15(1):99-116.

24. Chazan LK. Pioneiros da ultra-sonografia obstétrica no Brasil [relatório de pesquisa na internet]. Rio de Janeiro (RJ): Instituto de Medicina Social, Universidade do Estado do Rio de Janeiro; 2008 [acesso 2011 Jul 13]. Disponível em: http:/ / www.tesesims.uerj. br/lildbi/docsonline/pdf/chazan_lilian.pdf

25. Motta ECS. Resgate histórico de atenção ao parto: por um parto respeitoso [monografia]. Ipatinga (MG): Universidade Presidente Antônio Carlos; 2009. 